\title{
Hospitalizations associated with influenza and respiratory syncytial virus among patients attending a network of private hospitals in South Africa, 20072012
}

\author{
Robert Kyeyagalire $^{1 *}$, Stefano Tempia ${ }^{2,3,4}$, Adam L Cohen ${ }^{2,3}$, Adrian D Smith', Johanna M McAnerney ${ }^{4}$,
} Veerle Dermaux-Msimang ${ }^{4}$ and Cheryl Cohen ${ }^{4,5}$

\begin{abstract}
Background: Influenza and respiratory syncytial virus (RSV) infection are common causes of lower respiratory tract illness. Data on their burden in low and middle-income settings and from Africa are scarce. We aimed to estimate age-specific rates of hospitalization attributable to influenza and RSV among patients attending private hospitals in South Africa during 20072012.
\end{abstract}

Methods: We estimated annual age-specific rates of influenza- and RSV-associated hospitalization (that is respiratory hospitalizations likely due to influenza or RSV infection) by applying regression models to monthly administrative hospitalization data from a national private hospital group, using influenza and RSV surveillance data as covariates.

Results: Estimated mean hospitalization rates associated with seasonal influenza were 75 (95\% confidence interval $(\mathrm{Cl}), 41$ 108) and $3(95 \% \mathrm{Cl}, 2$ 5) per 100,000 person-years for all-respiratory and all-circulatory causes, respectively. Children $<1$ year and adults $\geq 75$ years were the most affected, with influenza-associated all-respiratory hospitalization rates estimated at $255(95 \% \mathrm{Cl}, 143$ 358) and 380 (95\% Cl, 227 506) per 100,000 person-years, respectively. Excess all-circulatory hospitalizations associated with seasonal influenza were only observed in adults $\geq 65$ years. Annual hospitalization rates associated with RSV averaged an estimate of 223 (95\% Cl, 128 317) per 100,000 person-years for all-respiratory causes. Among children <1 year, RSV-associated all-respiratory hospitalization rate of 7,601 (95\% Cl, 4,312-10,817) per 100,000 person-years was estimated.

Conclusions: Influenza and RSV substantially contributed to hospitalizations over the study period.

Keywords: Influenza virus, Respiratory syncytial virus, Hospitalization, South Africa

\section{Background}

In 2008, there were between 13 and 32 million cases of pneumonia attributed to influenza virus infection globally, with up to 110,000 deaths in children $<5$ years of age [1]. In the same age group, RSV infection accounted for 34 million hospitalizations and between 66,000 and 199,000 deaths [2]. The vast majority of these deaths likely due to influenza (influenza-associated) and RSV (RSV-associated) infection occurred in low and middle-income countries.

\footnotetext{
* Correspondence: rkyeyagalire@gmail.com

Equal contributors

'Nuffield Department of Population Health, University of Oxford, Oxford, UK Full list of author information is available at the end of the article
}

The burden of influenza- and RSV-associated hospitalizations across different age-groups has been well documented in high-income countries [3-14]. However, such information are limited in low and middle-income settings.

The influenza season in South Africa is well-defined and occurs during the southern hemisphere winter months (May to August) [15], while peak activity of RSV is observed from February to May [16]. Recent estimates of hospitalization burden associated with influenza and RSV in South Africa are available only from one large population-based surveillance site $[16,17]$. Since influenza and RSV infections are rarely confirmed by laboratory diagnosis we applied modeling approaches to estimate

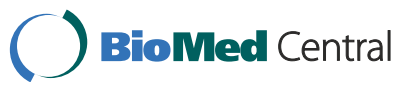

2014 Kyeyagalire et al.; licensee BioMed Central. This is an Open Access article distributed under the terms of the Creative Commons Attribution License (http://creativecommons.org/licenses/by/4.0), which permits unrestricted use, distribution, and reproduction in any medium, provided the original work is properly credited. The Creative Commons Public Domain Dedication waiver (http://creativecommons.org/publicdomain/zero/1.0/) applies to the data made available in this article, unless otherwise stated. 
age-specific influenza- and RSV-associated hospitalizations among individuals hospitalized at a network of private hospitals in South Africa from 2007 through 2012.

\section{Methods \\ Hospitalization data}

We obtained anonymized hospitalization data on admission diagnoses, that were coded according to the International Classification of Diseases, Tenth Revision (ICD-10), from a large network of private hospitals covering seven of the nine Provinces in South Africa (Eastern Cape, Free State, Gauteng, KwaZulu-Natal, Mpumalanga, North West, and Western Cape), for the period 2007 2012. We used the ICD-10 codes to compile age-specific monthly hospitalization time-series for all-respiratory (ICD-10: J00-J99), pneumonia and influenza (P\&I) (ICD-10: J10-J18 a subset of all-respiratory) and all-circulatory (ICD-10:I00199)) hospitalizations. Hospitalization data were analyzed in seven age categories: $<1,1$ 4, 5 19, 20 44, 45 64, 6574 and $\geq 75$ years of age.

\section{Population denominators}

We obtained countrywide annual population estimates for each of the seven age-groups from Statistics South Africa for the years 20072012 [18]. We calculated the proportion of the population that had private health insurance by using available data on annual national health insurance coverage [18]. We then standardized it to the national population by age-group and health insurance coverage, based on the age-grouping data provided by the largest health insurance group in South Africa [19]. After obtaining the age-standardized number of individuals with private health insurance per year, we used annual market share data to estimate the proportion registered to seek care from the private hospital network under study. We estimated the private hospital group to have a market share of $30 \%$ among the insured population, by computing their reported annual number of hospital beds against the total number of private hospital beds in the country for each of the six years studied. The resulting market share was consistent with previous independent reports on private hospital market distribution in the country [20].

South Africa had an estimated population of $51.3 \mathrm{mil}-$ lion in 2012; $16 \%$ of the population had private healthcare insurance, and the rest of the population sought care from public sector health facilities [18]. For this study we estimated the population served by the hospital group over the study period to represent 4.5 to 5.1 percent (1.9-2.5 million people) of the South Africa population.

\section{Influenza and RSV data}

We acquired influenza and RSV virological data, for the period 2007 2012, from a national database (the National Health Laboratory Services (NHLS) corporate data warehouse) that includes all patients tested for respiratory viruses at any of the 268 networked public health laboratories in South Africa. Data on influenza type and subtype were not available from the national database; these data were obtained from the National Institute for Communicable Diseases (NICD)s Viral Watch influenza surveillance programme, which receives samples from health practitioners across the country [15]. We considered an influenza type or subtype to be dominant during the influenza season when it accounted for more than $50 \%$ of the circulating viruses.

\section{Estimation of influenza- and RSV-associated hospitalizations}

To estimate the influenza- (seasonal and pandemic) and RSV-associated hospitalizations, we fitted age-specific regression models with a Poisson distribution and an identity link to monthly all-respiratory, all-circulatory and P\&I hospitalizations using methods previously described [21]. The identity link was selected because it is considered the most biologically plausible link to model the impact of pathogen circulation on mortality [22-25]. An identity link assumes additive (rather than multiplicative) effects of different pathogens on mortality. Through model selection procedures, we assessed the fit of models including higher order polynomials to represent more subtle time trends (1st to 6th degree) and additional harmonic terms representing annual and semi-annual periodicity $\left(\sin \left(2 t_{i} \pi / 12\right)\right.$ and $\cos \left(2 t_{i} \pi / 12\right) ; \sin \left(4 t_{i} \pi / 12\right)$ and $\left.\cos \left(4 t_{i} \pi / 12\right)\right)$. The final model was that for which the Akaike value was minimized, that is, the model that provided best fit to the data whilst maintaining parsimony. Variations of $<5 \%$ on model estimates were observed while using a negative binomial model as compared to the Poisson model; nonetheless the latter provided a better fit to the data. We also considered b-splines ( 1 knot per month was best) instead of polynomial terms to model background seasonality but polynomial terms provided the best fit to the South African data, perhaps because of the relatively crude monthly resolution of the data.

The full model included covariates for time trends and seasonal variation as well as viral circulation as follows:

$$
\begin{aligned}
& E\left(Y_{i, t}\right) \quad \beta_{0, i} \quad \beta_{1, i} \ddagger \quad \beta_{2, i} t^{2} \quad \beta_{3, i} t^{3} \quad \beta_{4, i} t^{4} \\
& \left.\left.\beta_{5, i} \sin 2 t \pi / 12\right] \quad \beta_{6, i} \cos 2 t \pi / 12\right] \\
& \beta_{7, i} \text { Seasonal_Influenza } t \text { ] } \\
& \left.\left.\beta_{8, i} \text { A H1N1 pdm09 } t\right] \quad \beta_{9, i} R S V t\right] \\
& \varepsilon_{i, t}
\end{aligned}
$$

$E\left(Y_{i, t}\right)$ represents age-specific number of deaths in age group $i$ and month $t ; \beta_{0, i}$ is the age-specific model 
constant; $\beta_{1, i}$ to $\beta_{4, i}$ are age-specific coefficients associated with time trends (linear to quartic polynomial terms); $\beta_{5, i}$ and $\beta_{6, i}$ are age-specific coefficients associated with harmonic terms accounting for annual background seasonal variations; $\beta_{7, i}$ to $\beta_{9, i}$ are age-specific coefficients representing the contribution of respiratory viruses to mortality (seasonal influenza $\left(\beta_{7, i}\right)$ : including $A(\mathrm{H} 1 \mathrm{~N} 1)$, $\mathrm{A}(\mathrm{H} 3 \mathrm{~N} 2)$ and $\mathrm{B}$; pandemic influenza $\left(\beta_{8, i}\right): \mathrm{A}(\mathrm{H} 1 \mathrm{~N} 1)$ pdm09; and RSV $\left.\left(\beta_{9, i}\right)\right)$; and $\varepsilon_{i, t}$ is the age-specific error term. Seasonal_influenza(t), A(H1N1)pdm09(t) and RSV ( $t$ ) are proxies for monthly viral activity, estimated as the monthly number of specimen testing positive for influenza or RSV over the annual number of specimens tested for the specific pathogen. We used standardization by the annual total of all specimens tested for the specific pathogen to reduce possible bias associated with differences in specimen sampling and laboratory methods over time $[14,21]$.

To estimate the excess hospitalization associated with influenza and RSV, we subtracted predicted monthly hospitalizations from a full model incorporating all viral terms from an expected baseline. The baseline was obtained by setting the viral covariates to zero and the annual excess hospitalizations were estimated as the sum of the monthly excess hospitalizations for each year. We obtained 95\% confidence intervals (CI) for the estimated excess hospitalizations using bootstrap resampling on blocks of calendar years (12-month block resampling with replacement) over 1000 replications $[21,26]$. For each resampled dataset we refitted the Poisson regression model and the 95\% CI were obtained from the 2.5th and 97.5th percentiles of the estimated influenza- and RSV-associated hospitalizations from the 1000 resampled datasets. The statistical analysis was implemented using STATA version 12 (StataCorp, Texas, USA).

\section{Ethical considerations}

Since the analysis used only de-identified and aggregated hospitalization and laboratory data, this study was considered to be exempt from human subjects ethics review.

\section{Results}

\section{Rates of hospitalization}

South Africa had a population of approximately 51.3 million people in 2012. Over the study period, an annual mean of 530,345 hospitalizations (range 491,155-576,634) across all age-groups occurred in the private hospital network for all causes, of which 51,899 (10\%) were attributed to respiratory causes and 28,904 (6\%) to circulatory causes. The mean annual rates of all-respiratory and P\&I causes of hospitalization were highest in the $<1$ and $\geq 75$ year age-groups and lowest in the 2044 year age-group (Table 1). The rates of hospitalization attributed to circulatory illness increased with increasing age and were highest among those $\geq 75$ years of age.

\section{Influenza and RSV laboratory surveillance}

Means of 8,922 (range 4,720-15,321) and 6,640 (range 2,637-10,331) samples were tested annually for influenza and RSV, respectively. The mean annual number of specimens testing positive was 2,099 (23\%) for influenza virus and 1,194 (18\%) for RSV. During the study period, the influenza season peaked between June and August, while RSV peak activity was observed between February and April (Figure 1A). In 2009, a first wave of influenza peaked in June and was mainly due to $\mathrm{A}(\mathrm{H} 3 \mathrm{~N} 2)$, followed by a second influenza wave that peaked in August and was caused by A (H1N1)pdm09.

\section{Influenza- and RSV-associated hospitalizations}

The estimated annual rates of all-respiratory hospitalizations attributed to seasonal influenza (excluding A (H1N1)pdm09) ranged from 54.2 to 111.9 per 100,000 person-years (Table 2). Annual circulatory hospitalizations associated with influenza were estimated to range from 2.3 to 4.8 per 100,000 person-years. Rates of RSV-associated hospitalizations among the $<20$ year age-group ranged from 195.9 to 262.7 per 100,000 person-years for all-respiratory illnesses over the study period.

Estimated mean annual all-respiratory hospitalization rates associated with seasonal influenza were highest among children aged $<1$ year (255 per 100,000 personyears) and individuals aged $\geq 75$ years (380 per 100000 person years) (Table 3). Seasonal influenza-associated all-circulatory hospitalizations were only estimated among individuals $\geq 65$ years of age.

In 2009 the estimated rate of all-respiratory hospitalizations associated with influenza $\mathrm{A}(\mathrm{H} 1 \mathrm{~N} 1) \mathrm{pdm} 09$ was 136 per 100,000 person-years, almost two times higher than the mean influenza-associated hospitalizations during non-pandemic years (Table 3). The rates of hospitalizations associated with influenza A(H1N1)pdm09 among individuals $>5$ years of age were higher than mean seasonal influenza hospitalization rates (especially in the 519 age group), but lower among elderly individuals.

The estimated mean annual rates of RSV-associated all-respiratory hospitalizations decreased with age; and it was highest among $<1$ year age-group $(7,601$ per 100,000 person-years) and lowest among 519 year age-group (57 per 100,000 person-years) (Table 3 ). Similar trends were observed among pneumonia and influenza cases that were associated with RSV. Our model did not estimate any RSV-associated hospitalizations among individuals $\geq 20$ years of age. 
Table 1 Mean annual hospitalization rates and population at risk among individuals with health insurance and served by the studied private hospital group in South Africa, 20072012

\begin{tabular}{|c|c|c|c|c|}
\hline \multirow{3}{*}{$\begin{array}{l}\text { Age-groups } \\
\text { (in years) }\end{array}$} & \multirow{3}{*}{$\begin{array}{l}\text { Mean annual population } \\
\text { in hospital group }{ }^{\mathrm{a}} \text { (range) }\end{array}$} & \multicolumn{3}{|l|}{ Cause of hospitalization } \\
\hline & & $\begin{array}{l}\text { Respiratory }{ }^{\mathbf{b}} \text { (including pneumonia } \\
\text { and influenza) }\end{array}$ & Pneumonia and influenza ${ }^{c}$ & Circulatory $^{d}$ \\
\hline & & Mean annual rates ${ }^{e}\left(\right.$ range $\left.^{f}\right)$ & Mean annual rates ${ }^{e}$ (range $^{f}$ ) & Mean annual rates ${ }^{e}\left(\right.$ range $\left.^{f}\right)$ \\
\hline$<1$ & 39529 (33009 43103) & $29043(2550032697)$ & $11542(10148$ 13236) & $226(186300)$ \\
\hline $1-4$ & $162117(132038180020)$ & $6083(47417496)$ & $1663(1359$ 1846) & $38(3046)$ \\
\hline 5-19 & 478789 (405825 519777) & $2176\left(\begin{array}{ll}1887 & 2564\end{array}\right)$ & 433 (337 519) & $152(139$ 187) \\
\hline $20-44$ & 996137 (838835 1082658) & $1322(1172$ 1594) & 409 (359 467) & $841(772$ 1036) \\
\hline $45-64$ & 494431 (413592 534990) & $2026(18002293)$ & $718(623781)$ & $3795(35114570)$ \\
\hline 65-74 & $103672(79611$ 118082) & $3742(34344521)$ & $1417\left(\begin{array}{lll}1324 & 1718\end{array}\right)$ & 8677 (7546 10894) \\
\hline$\geq 75$ & $48562(2689354317)$ & 7507 (65959327) & $3873(34834773)$ & $15175(1399018814)$ \\
\hline All & 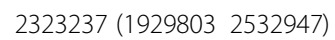 & $2393(2181 \quad 2767)$ & 709 (654 778) & $1938(1795$ 2287) \\
\hline
\end{tabular}

${ }^{a}$ Determined by calculating proportion of age-specific population with health insurance, who are served by the hospital group under study, based on their market share estimates.

${ }^{\mathrm{b}}$ Hospitalized with a diagnosis of International Classification of Diseases Tenth Revision (ICD-10) codes of J00-J99.

${ }^{\mathrm{C}}$ Hospitalized with a diagnosis of ICD-10: J10-J18.

${ }^{\mathrm{d}}$ Hospitalized with a diagnosis of ICD-10: 100-199.

${ }^{\mathrm{e}} \mathrm{Hospitalization}$ rate per 100,000 person-years.

f Rate ranges over the six years studied, 2007 to 2012.

\section{Discussion}

Influenza and RSV substantially contributed to hospitalizations in South Africa throughout the study period. Hospitalization rates associated with seasonal influenza were highest among children $<1$ year of age and individuals aged $\geq 75$ years, while RSV mostly affected children $<5$ years of age. We did not estimate any RSV-associated hospitalizations among individuals aged $\geq 20$ years.

Elevated influenza-associated hospitalizations have been reported among infants and elderly individuals in other studies conducted in the United States and Europe $[8,13,14]$. Estimated rates of influenza-associated hospitalizations per 100,000 person-years in South Africa among children $<1$ (255) and 14 (205) years of age for all-respiratory causes were elevated, compared with the United States (151 in children $<1$ year of age and 39 among children 14 years of age for respiratory and circulatory cause of hospitalization) [14]. Estimated rates of influenza-associated P\&I hospitalizations (41 per 100,000 person-year) observed in our study were similar to estimates of influenza-associated hospitalizations (49 and 54 per 100,000 person-year in 2010 and 2011, respectively) derived from a large population-based public hospital surveillance site in Soweto, South Africa, where patients presenting with acute lower respiratory tract infection were systematically enrolled and tested for influenza from 2009 through 2011 [17].

Rates of influenza A(H1N1)pdm09-associated allrespiratory hospitalizations in 2009 in South Africa were estimated to be approximately double those observed during non-pandemic years and disproportionately affected young individuals (especially the 519 year age-group), with the elderly being the least affected. Studies on the 2009 influenza pandemic previously conducted in the United States [27,28], Canada [29], Argentina [30] and Italy [31] observed similar patterns.

We identified an elevated burden of RSV compared to influenza infection among children $<5$ years of age. A study conducted in children aged $<5$ years with respiratory infections that attended public sector hospitals in South Africa showed a $30 \%$ positivity proportion for RSV compared to only $4 \%$ for influenza [32]. Another study conducted in the United States using a methodology similar to ours found RSV-associated hospitalizations to be 16 times higher than influenza among children $<1$ year of age $[14,33]$. In our study, estimated mean annual rates per 100,000 person-years of RSV-associated P\&I hospitalizations among children $<1(3,055)$ and 14 (457) years of age were similar to those observed from a population-based surveillance site in Soweto, South Africa, in 20102011 (2,400-3,200 in children <1 year of age and 500600 in children aged 14 years) [16].

Our model did not estimate any excess hospitalizations associated with RSV among elderly individuals, although other studies have previously reported morbidity and mortality among adults infected with laboratory-confirmed RSV [34,35]. Studies conducted in Kenya and South Africa that compared the RSV prevalence among patients hospitalized with severe acute respiratory illness (SARI) to controls found that RSV infection was associated with hospitalization among children $<5$ years of age, but no association was found among individuals $\geq 5$ years old [36,37]. Studies conducted in Egypt, Guatemala, Kenya and Thailand, where patients of all ages hospitalized 

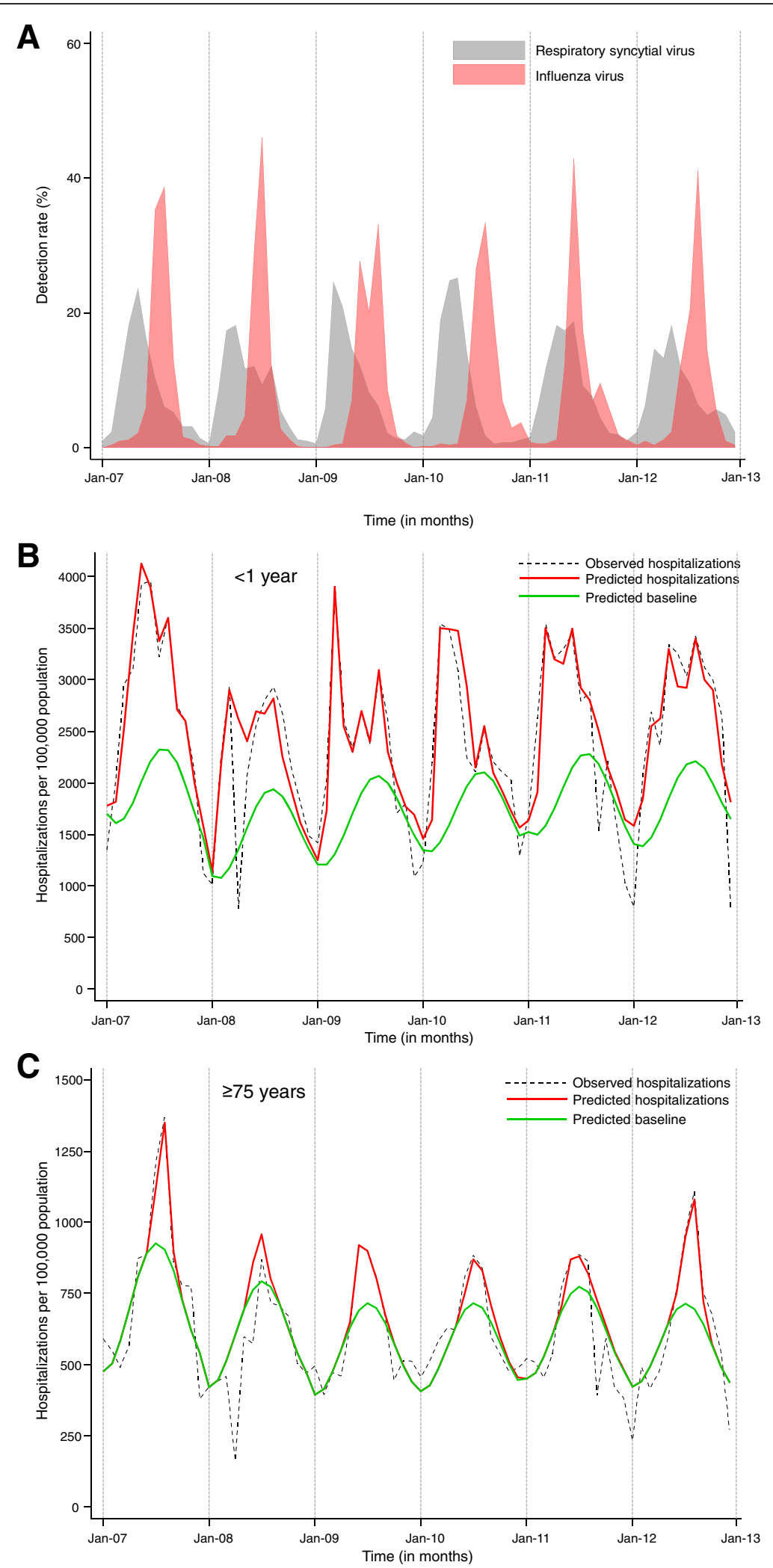

Figure 1 (See legend on next page.) 
(See figure on previous page.)

Figure 1 Monthly detection of influenza and respiratory syncytial virus and hospitalization rates among individuals attending private hospitals in South Africa, 2007 2012. A: Detection rate (i.e., monthly number of positive specimens divided by total specimens) of influenza and respiratory syncytial virus (all ages). B: Observed all-respiratory hospitalizations and predicted hospitalizations and baseline (Poisson model) by month in children $<1$ year of age. C: Observed all-respiratory hospitalizations and predicted hospitalizations and baseline (Poisson model) by month in individuals $\geq 75$ years of age.

with acute lower-respiratory tract infections were systematically enrolled and tested using molecular techniques, reported RSV detection rates of $<1-5 \%$ among individuals $\geq 50$ or $\geq 65$ years of age compared to RSV detection rates of $>20 \%$ in infants and young children [38-40]. In South Africa in 2009 2010, the RSV detection rate among patients hospitalized with SARI decreased from $26.8 \%$ among infants $<1$ year of age to $0.9 \%$ among individuals $\geq 65$ years, compared with an influenza detection rate of approximately $8-12 \%$ across all age groups in the same study population [33]. This may suggest that although RSV can be detected among older children and adults, it may play a less important role as a pathogen in this group.
A recent study conducted to estimate adult mortality associated with influenza and RSV in South Africa (using a methodology similar to ours) found only influenza- and not RSV-associated mortality among individuals older than 44 years of age [41]. While cases of RSV-associated hospitalization and mortality among elderly individuals are expected to occur in South Africa, our modelling approach may have failed to statistically estimate a small number of cases. Other national estimates of influenzaand RSV-associated mortality among adult and elderly individuals have been determined mainly using modelling approaches similar to ours and in settings where the influenza and RSV seasons are more synchronous [7,42]. Ecological studies conducted in settings similar to ours,

Table 2 Annual variation in influenza types/subtypes and estimated annual influenza- and respiratory syncytial virus-associated hospitalizations among individuals (all ages) attending a private hospital group in South Africa, 20072012

\begin{tabular}{|c|c|c|c|c|c|}
\hline \multirow[t]{3}{*}{ Year } & \multicolumn{5}{|l|}{ Estimated hospitalizations } \\
\hline & \multicolumn{3}{|c|}{ Influenza (excluding A(H1N1)pdm09 in 2009) } & \multicolumn{2}{|l|}{ RSV } \\
\hline & Dominant type/subtype & Number ${ }^{a}$ & Rate $^{\text {b }}$ & Number ${ }^{a}$ & Rate $^{\mathbf{b}}$ \\
\hline \multicolumn{6}{|c|}{ All-respiratory (including pneumonia and influenza) } \\
\hline 2007 & $\mathrm{~A}(\mathrm{H} 3 \mathrm{~N} 2)$ & 2151 & 112 & 5098 & 263 \\
\hline 2008 & $A(\mathrm{H} 1 \mathrm{~N} 1)$ & 1707 & 73 & 4889 & 207 \\
\hline 2009 & $\mathrm{~A}(\mathrm{H} 3 \mathrm{~N} 2)$ & 1934 & 79 & 6432 & 261 \\
\hline 2010 & B & 1660 & 66 & 4987 & 197 \\
\hline 2011 & A (H1N1)pdm09 & 1637 & 72 & 4475 & 196 \\
\hline 2012 & $\mathrm{~A}(\mathrm{H} 3 \mathrm{~N} 2)$ & 1282 & 54 & 5112 & 216 \\
\hline \multicolumn{6}{|c|}{ Pneumonia and influenza only } \\
\hline 2007 & $\mathrm{~A}(\mathrm{H} 3 \mathrm{~N} 2)$ & 1136 & 57 & 2011 & 102 \\
\hline 2008 & $\mathrm{~A}(\mathrm{H} 1 \mathrm{~N} 1)$ & 902 & 37 & 1929 & 80 \\
\hline 2009 & $\mathrm{~A}(\mathrm{H} 3 \mathrm{~N} 2)$ & 1022 & 41 & 2538 & 101 \\
\hline 2010 & B & 877 & 34 & 1968 & 76 \\
\hline 2011 & A (H1N1)pdm09 & 865 & 37 & 1766 & 75 \\
\hline 2012 & $\mathrm{~A}(\mathrm{H} 3 \mathrm{~N} 2)$ & 677 & 28 & 2017 & 83 \\
\hline \multicolumn{6}{|c|}{ All-circulatory } \\
\hline 2007 & $\mathrm{~A}(\mathrm{H} 3 \mathrm{~N} 2)$ & 92 & 5 & & \\
\hline 2008 & $\mathrm{~A}(\mathrm{H} 1 \mathrm{~N} 1)$ & 73 & 3 & & \\
\hline 2009 & $\mathrm{~A}(\mathrm{H} 3 \mathrm{~N} 2)$ & 83 & 3 & & \\
\hline 2010 & $B$ & 71 & 3 & & \\
\hline 2011 & A (H1N1)pdm09 & 70 & 3 & & \\
\hline 2012 & A $(\mathrm{H} 3 \mathrm{~N} 2)$ & 55 & 2 & & \\
\hline
\end{tabular}

${ }^{\mathrm{a} E s t i m a t e d ~ n u m b e r ~ o f ~ p a t i e n t s ~ s e r v e d ~ i n ~ t h e ~ p r i v a t e ~ h o s p i t a l ~ g r o u p ~ p e r ~ c a u s e ~ o f ~ h o s p i t a l i z a t i o n ~ p e r ~ y e a r . ~}$ ${ }^{\mathrm{b}}$ Hospitalization rate per 100,000 person-years. 
Table 3 Estimated mean annual influenza- and respiratory syncytial virus-associated hospitalizations by age group among individuals attending a private hospital group in South Africa, 20072012

\begin{tabular}{|c|c|c|c|c|c|c|c|c|c|}
\hline \multirow{3}{*}{$\begin{array}{l}\text { Age groups } \\
\text { (in years) }\end{array}$} & \multicolumn{6}{|l|}{ Influenza (mean) } & \multicolumn{3}{|c|}{ Respiratory syncytial virus (Mean) } \\
\hline & \multicolumn{3}{|l|}{ Seasonal } & \multicolumn{3}{|c|}{ A(H1N1)pdm09 in 2009} & & & \\
\hline & $\begin{array}{l}\text { Number } \\
(95 \% \mathrm{Cl})\end{array}$ & $\begin{array}{l}\text { Rate }^{\mathrm{a}} \\
(95 \% \mathrm{Cl})\end{array}$ & $\begin{array}{l}\text { Percentage over } \\
\text { total hospitalizations } \\
(95 \% \mathrm{Cl})\end{array}$ & $\begin{array}{l}\text { Number } \\
(95 \% \mathrm{Cl})\end{array}$ & $\begin{array}{l}\text { Rate }^{\mathrm{a}} \\
(95 \% \mathrm{Cl})\end{array}$ & $\begin{array}{l}\text { Percentage over } \\
\text { total hospitalizations } \\
(95 \% \mathrm{Cl})\end{array}$ & $\begin{array}{l}\text { Number } \\
(95 \% \mathrm{Cl})\end{array}$ & $\begin{array}{l}\text { Rate }^{\mathrm{a}} \\
(95 \% \mathrm{Cl})\end{array}$ & $\begin{array}{l}\text { Percentage over } \\
\text { total hospitalizations } \\
(95 \% \mathrm{Cl})\end{array}$ \\
\hline \multicolumn{10}{|c|}{ All-respiratory } \\
\hline$<1$ & $99\left(\begin{array}{ll}56 & 142\end{array}\right)$ & $255(143358)$ & $1.2(0.8-1.6)$ & $260(148$ 372) & $621(354888)$ & $3.1(2.2-4.0)$ & $2990(17044276)$ & 7601 (4312 10817) & $36.2(25.3-47.1)$ \\
\hline $1-4$ & $326(196456)$ & 205 (121 282) & $4.3(3.0-5.6)$ & 197 (118 276) & $116\left(\begin{array}{ll}70 & 162\end{array}\right)$ & $2.4(1.7-3.1)$ & $1902(11412663)$ & $1182(704$ 1643) & $25.7(17.7-33.7)$ \\
\hline 5-19 & $261(117405)$ & $55(2584)$ & $2.7(1.9-3.5)$ & $1183(532$ 1834) & $233(105361)$ & $11.8(8.1-15.5)$ & $272(122$ 422) & $57(2688)$ & $2.8(1.9-3.7)$ \\
\hline $20-44$ & 366 (179 553) & $37(18$ 55) & $2.9(2.0-3.8)$ & 922 (452 2392) & $87\left(\begin{array}{ll}4 & 131\end{array}\right)$ & $7.0(4.8-9.2)$ & & & \\
\hline $45-64$ & 341 (198 484) & 70 (40 98) & $3.5(2.3-4.7)$ & $588(341835)$ & $112(65159)$ & $5.9(3.8-8.0)$ & & & \\
\hline 65-74 & $154(92$ 216) & 154 (89 208) & $4.1(2.6-5.6)$ & $148(89207)$ & $139\left(\begin{array}{ll}73 & 163\end{array}\right)$ & $4.0(2.5-5.5)$ & & & \\
\hline $75+$ & $178\left(\begin{array}{ll}110 & 246\end{array}\right)$ & $380(227506)$ & $5.2(3.5-6.9)$ & $61(38$ 84) & $117\left(\begin{array}{ll}73 & 163\end{array}\right)$ & $1.7(1.1-2.3)$ & & & \\
\hline All & 1725 (949 2501) & $75\left(\begin{array}{ll}41 & 108\end{array}\right)$ & $3.1(2.2-4.0)$ & 3359 (1718 5001) & $136(70203)$ & $5.9(4.1-7.7)$ & $5164(2968$ 7360) & $223\left(\begin{array}{lll}128 & 317\end{array}\right)$ & $9.3(6.4-12.2)$ \\
\hline \multicolumn{10}{|c|}{ Pneumonia and influenza } \\
\hline$<1$ & $94(54$ 134) & $241(136340)$ & $6.9(4.8-9.0)$ & 204 (116 292) & $488(278$ 697) & $12.2(8.5-15.9)$ & $1201(685$ 1717) & 3055 (1732 4345) & $34.6(24.2-45.0)$ \\
\hline $1-4$ & $125(75$ 175) & $78\left(\begin{array}{ll}4 & 108\end{array}\right)$ & $8.1(5.6-10.6)$ & $187(112$ 262) & $110(66$ 154) & $13.5(9.3-17.7)$ & $735(441$ 1029) & $457(272635)$ & $25.9(17.9-33.9)$ \\
\hline $5-19$ & $129\left(\begin{array}{ll}58 & 200\end{array}\right)$ & $27(1242)$ & $7.6(5.2-10.0)$ & $678(3051051)$ & $133(60$ 207) & $38.9(26.8-51.0)$ & $100(45155)$ & $21\left(\begin{array}{ll}9 & 32\end{array}\right)$ & $5.9(4.1-7.7)$ \\
\hline $20-44$ & $198(97$ 299) & $20(10 \quad 30)$ & $7.2(4.9-9.5)$ & 481 (236 726) & $45(2269)$ & $12.0(8.2-15.8)$ & & & \\
\hline $45-64$ & $195(113$ 277) & $40(2356)$ & $7.8(5.1-10.5)$ & $278\left(\begin{array}{ll}161 & 395\end{array}\right)$ & $53(3175)$ & $8.1(5.3-10.9)$ & & & \\
\hline 65-74 & $85\left(\begin{array}{ll}51 & 119\end{array}\right)$ & $85(49$ 115) & $6.1(3.8-8.4)$ & $83\left(\begin{array}{ll}50 & 116\end{array}\right)$ & $78\left(\begin{array}{ll}4 & 110\end{array}\right)$ & $5.9(3.7-8.1)$ & & & \\
\hline $75+$ & $120(74166)$ & $256(153341)$ & $6.9(4.6-9.2)$ & $29(1840)$ & $56(3577)$ & $2.1(1.4-2.8)$ & & & \\
\hline All & $946\left(\begin{array}{ll}522 & 1370\end{array}\right)$ & 41 (22 59) & $7.7(5.4-10.0)$ & $1940(998 \quad 2882)$ & $77\left(\begin{array}{ll}41 & 117\end{array}\right)$ & $11.3(7.9-14.7)$ & 2036 (1171 2901) & $86\left(\begin{array}{ll}50 & 125\end{array}\right)$ & $12.2(8.4-16.0)$ \\
\hline \multicolumn{10}{|c|}{ All-circulatory } \\
\hline \multicolumn{10}{|l|}{$<1$} \\
\hline \multicolumn{10}{|l|}{$1-4$} \\
\hline \multicolumn{10}{|l|}{$5-19$} \\
\hline \multicolumn{10}{|l|}{ 20-44 } \\
\hline \multicolumn{10}{|l|}{$45-64$} \\
\hline 65-74 & $23\left(\begin{array}{ll}10 & 36\end{array}\right)$ & $23\left(\begin{array}{ll}10 & 34\end{array}\right)$ & $0.2(0.1-0.3)$ & $91\left(\begin{array}{ll}55 & 127\end{array}\right)$ & $86\left(\begin{array}{ll}52 & 120\end{array}\right)$ & $1.0(0.6-1.4)$ & & & \\
\hline $75+$ & $50(2575)$ & $107\left(\begin{array}{ll}51 & 154\end{array}\right)$ & $0.7(0.5-0.9)$ & $14(9$ 19) & 28 (17 37) & $0.2(0.1-0.3)$ & & & \\
\hline All & $73(35$ 111) & $3(25)$ & $0.1(0.06-0.14)$ & $105\left(\begin{array}{ll}63 & 147\end{array}\right)$ & $4(36)$ & $0.1(0.5-0.15)$ & & & \\
\hline
\end{tabular}

aHospitalization rate per 100,000 person-years. 
where influenza and RSV peak activities are not synchronous, may assist in better differentiating the relative burden of these pathogens especially in adults. While in our study we report low to moderate RSV-associated hospitalization among individuals $\geq 5$ years of age, clinical diagnosis and surveillance for both influenza and RSV should be continued and strengthened, and may be leveraged to better understand the burden and severity associated with RSV infection in older age groups.

Our study has limitations that warrant discussion. Firstly, the lack of weekly hospitalization data may have hindered the ability to more accurately estimate the relative contribution of RSV and influenza virus on hospitalizations. In addition, the monthly temporal resolution of our data did not allow us to include viral circulation proxies for each season. Our approach may underestimate the annual variation of influenza-associated hospitalizations in our study. Secondly, lack of availability of influenza and RSV incidence data hampered our ability to consider more refined indicators of respiratory virus activity in our time series models as reported by Goldstein et al. $[25,26]$. Thirdly, we were not powered to estimate the association of influenza and RSV circulation with more refined causes of hospitalization. In addition, data on the circulation of respiratory viruses other than influenza and RSV were not available for the entire study period and were not included in our study. This may potentially overestimate the hospitalizations attributed to influenza or RSV infection. Nonetheless, the estimates obtained in our study are similar to those obtained from case-based studies in South Africa [16,17]. Furthermore case-based surveillance implemented among patients hospitalized with severe acute respiratory illness (SARI) in South Africa from 2009 indicated peak activities of human metapneumovirus and parainfluenza virus type 3 after the influenza season (September to November) with an annual detection rate among SARI cases of approximately $4 \%$ for each pathogen. Given the different seasonality of these pathogens minimal effect is expected on the influenza- and RSV-associated hospitalizations estimated with our model. All other respiratory viruses tested under the SARI surveillance programme (e.g. adenovirus, enterovirus, parainfluenza virus types 1 and 2, and rhinovirus) were detected year-around without clear seasonality [33]. Fourthly, we could only estimate influenza- and RSVassociated hospitalization using data from a proportion of private hospitals in South Africa as national hospitalization data, from all private and public health facilities, were not available. In addition we estimated the service population of the hospital group used in this study based on available data on number of individuals insured and market share of this hospital group. The representativeness of our estimations for national population is therefore uncertain. Nonetheless, our incidence rate estimates were similar to those obtained using active, prospective surveillance from a large population-based public sentinel hospital $[16,17]$, and may be reasonably representative of the total population.

\section{Conclusion}

Our study found that influenza and RSV were associated with substantial hospitalization rates in South Africa, with influenza responsible for hospitalizations across all agegroups and RSV affecting mainly individuals $<5$ years of age. Vaccination remains the most effective method of preventing influenza virus infection [43], and the effectiveness of RSV candidate vaccines is being evaluated [44,45] and when available could potentially substantially reduce the elevated burden of hospitalization especially in young children.

\section{Abbreviations}

NICD: National Institute of Communicable Diseases, of South Africa; P\&l: Pneumonia and influenza; RSV: Respiratory syncytial virus; SARI: Severe acute respiratory illness.

\section{Competing interests}

The authors declare that they have no competing interests.

\section{Authors contributions}

RK participated in the design of the study, acquisition of data, statistical analysis and interpretation of findings, and drafted the manuscript. ST participated in the concept and design of the study, performed the statistical analysis and interpretation of the data, and critically reviewed the manuscript. ALC participated in the concept and design of the study, acquisition of data and critically reviewed the manuscript. ADS contributed to the design of the study and reviewed the manuscript. JMM contributed to the acquisition of the data and critical review of the manuscript. VMV contributed to the concept of the study and critical review of the manuscript. CC contributed to the concept and design of the study, supported the acquisition of data, participated in interpretation of findings and critically reviewed the manuscript. All authors read and approved the final manuscript.

\section{Acknowledgements}

We thank the management of Netcare Limited for providing us access to hospitalization data for their network of private hospitals in South Africa, and the Li Ka Shing Foundation for providing funding to the first author during this study and throughout his MSc programme at the University of Oxford. We also acknowledge the support of Jerome Tokars and Ann Bauman at CDC Atlanta in critically reviewing this article.

\section{Author details}

${ }^{1}$ Nuffield Department of Population Health, University of Oxford, Oxford, UK. ${ }^{2}$ Influenza Division, Centers for Disease Control and Prevention, Atlanta, GA, USA. ${ }^{3}$ Influenza Division, Centers for Disease Control and Prevention, Pretoria, South Africa. ${ }^{4}$ Center for Respiratory Diseases and Meningitis, National Institute for Communicable Diseases of the National Health Laboratory Service, Johannesburg, South Africa. ${ }^{5}$ School of Public Health, Faculty of Health Sciences, University of Witwatersrand, Johannesburg, South Africa.

Received: 23 July 2014 Accepted: 10 December 2014

Published online: 16 December 2014

\section{References}

1. Nair H, Brooks WA, Katz M, Roca A, Berkley JA, Madhi SA, Simmerman JM, Gordon A, Sato M, Howie S, Krishnan A, Ope M, Lindblade KA, Carosone-Link P, Lucero M, Ochieng W, Kamimoto L, Dueger E, Bhat N, Vong S, Theodoratou E, Chittaganpitch M, Chimah O, Balmaseda A, Buchy P, Harris E, Evans V, Katayose M, Gaur B, O Callaghan-Gordo C, et al: Global burden of respiratory infections 
due to seasonal influenza in young children: a systematic review and meta-analysis. Lancet 2011, 378(9807):1917 1930

2. Nair H, Nokes DJ, Gessner BD, Dherani M, Madhi SA, Singleton RJ, O Brien $\mathrm{KL}$, Roca A, Wright PF, Bruce N, Chandran A, Theodoratou E, Sutanto A, Sedyaningsih ER, Ngama M, Munywoki PK, Kartasasmita C, Simes EA, Rudan I, Weber MW, Campbell H: Global burden of acute lower respiratory infections due to respiratory syncytial virus in young children: a systematic review and meta-analysis. Lancet 2010, 375(9725):1545 1555.

3. Boyce TG, Mellen BG, Mitchel EF Jr, Wright PF, Griffin MR: Rates of hospitalization for respiratory syncytial virus infection among children in Medicaid. J Pediatr 2000, 137(6):865 870.

4. Chiu SS, Lau YL, Chan KH, Wong WHS, Peiris JM: Influenza-related hospitalizations among children in Hong Kong. N Engl J Med 2002, 347(26):2097 2103

5. Dawood FS, Fiore A, Kamimoto L, Bramley A, Reingold A, Gershman K, Meek J, Hadler J, Arnold KE, Ryan P, Lynfield R, Morin C, Mueller M, Baumbach J, Zansky S, Bennett NM, Thomas A, Schaffner W, Kirschke D, Finelli L: Burden of Seasonal Influenza Hospitalization in Children, United States, 2003 to 2008. J Pediatr 2010, 157(5):808 814.

6. Donaldson L, Rutter PD, Ellis BM, Greaves FE, Mytton OT, Pebody RG, Yardley IE: Mortality from pandemic A/H1N1 2009 influenza in England: public health surveillance study. BMJ 2009, 339:b5213.

7. Hardelid P, Pebody R, Andrews N: Mortality caused by influenza and respiratory syncytial virus by age group in England and Wales 1999 2010. Influenza Other Respi Viruses 2013, 7(1):35 45.

8. Jansen AG, Sanders EA, Hoes AW, van Loon AM, Hak E: Influenza-and respiratory syncytial virus-associated mortality and hospitalisations. Eur Respir J 2007, 30(6):1158 1166.

9. Johnson JI, Ratard R: Respiratory syncytial virus-associated hospitalizations in Louisiana. J La State Med Soc 2012, 164(5):268 273.

10. Molinari NM, Ortega-Sanchez IR, Messonnier ML, Thompson WW, Wortley $P M$, Weintraub E, Bridges CB: The annual impact of seasonal influenza in the US: Measuring disease burden and costs. Vaccine 2007, 25(27):5086 5096.

11. Newall AT, Wood JG, Maclntyre CR: Influenza-related hospitalisation and death in Australians aged 50 years and older. Vaccine 2008, 26(17):2135 2141

12. Pitman RJ, Melegaro A, Gelb D, Siddiqui MR, Gay NJ, Edmunds WJ: Assessing the burden of influenza and other respiratory infections in England and Wales. J Infect 2007, 54(6):530 538 .

13. Thompson WW, Shay DK, Weintraub E, Brammer L, Bridges CB, Cox NJ, Fukuda K: Influenza-associated hospitalizations in the United States. JAMA 2004, 292(11):1333 1340.

14. Zhou H, Thompson WW, Viboud CG, Ringholz CM, Cheng P, Steiner C, Abedi GR, Anderson LJ, Brammer L, Shay DK: Hospitalizations associated with influenza and respiratory syncytial virus in the United States, 1993 2008. Clin Infect Dis 2012, 54(10):1427 1436.

15. McAnerney JM, Cohen C, Moyes J, Besselaar TG, Buys A, Schoub BD, Blumberg L: Twenty-five years of outpatient influenza surveillance in South Africa, 1984 2008. J Infect Dis 2012, 206(Suppl 1):S153 S158.

16. Moyes J, Cohen C, Pretorius M, Groome M, von Gottberg A, Wolter N, Walaza S, Haffejee S, Chhagan M, Naby F, Cohen AL, Tempia S, Kahn K, Dawood H, Venter M, Madhi SA, South African Severe Acute Respiratory Illness Surveillance Group: Epidemiology of respiratory syncytial virus-associated acute lower respiratory tract infection hospitalizations among HIV-infected and HIV-uninfected South African children, 2010 2011. J Infect Dis 2013, 208(Suppl 3):S217 S226.

17. Cohen C, Moyes J, Tempia S, Groom M, Walaza S, Pretorius M, Dawood H, Chhagan M, Haffejee S, Variava E, Kahn K, Tshangela A, von Gottberg A, Wolter N, Cohen AL, Kgokong B, Venter M, Madhi SA: Severe influenza-associated respiratory infection in high HIV prevalence setting, South Africa, 2009 2011. Emerg Infect Dis 2013, 19(11):1766 1774.

18. Statistics South Africa. General Household Survey 2011. 2012. [http://www. statssa.gov.za/publications/P0318/P0318April2012.pdf] Accessed July 03, 2013

19. Malan D: Press release: robust financial and operational performance entrenches leadership position of Discovery Health Medical Scheme. 2013. [http://www.mynewsdesk.com/za/discovery-holdings-ltd/ pressreleases/robust-financial-and-operational-performance-in-conjunctionwith-best-practice-governance-entrenches-leadership-position-of-discoveryhealth-879014] Accessed July 15, 2013
20. Kahn T: Netcares earnings rise, helped in part by a weaker rand. 2013 . [http://www.bdlive.co.za/business/healthcare/2013/05/20/netcares-earningsrise-helped-in-part-by-weaker-rand] Accessed May 20, 2013

21. Tempia S, Walaza S, Viboud C, Cohen AL, Madhi SA, Venter M, McAnerney $J M$, Cohen C: Mortality associated with seasonal and pandemic influenza and respiratory syncytial virus among children less than 5 years of age in a high HIV-prevalence setting - South Africa, 1998 2009. Clin Infect Dis 2014, 58(9):1241 1249

22. Gay NJ, Andrews NJ, Trotter CL, Edmunds WJ: Estimating deaths due to influenza and respiratory syncytial virus. JAMA 2003, 289(19):2499. author reply 25002

23. Simonsen L, Blackwelder WC, Reichert TA, Miller MA: Estimating deaths due to influenza and respiratory syncytial virus. JAMA 2003, 289(19):24992 2500. author reply 25002

24. Glezen WP, Couch RB: Estimating deaths due to influenza and respiratory syncytial virus. JAMA 2003, 289(19):2500. author reply 25002.

25. Goldstein E, Viboud C, Charu V, Lipsitch M: Improving the estimation of influenza-related mortality over a seasonal baseline. Epidemiology 2012, 23(6):829 838

26. Weinberger DM, Simonsen $L$, Jordan $R$, Steiner C, Miller M, Viboud C: Impact of the 2009 influenza pandemic on pneumococcal pneumonia hospitalizations in the United States. J Infect Dis 2012, 205(3):458 465.

27. Louie JK, Acosta M, Winter K, Jean C, Gavali S, Schechter R, Vugia D, Harriman K, Matyas B, Glaser CA: Factors associated with death or hospitalization due to pandemic 2009 influenza A (H1N1) infection in California. JAMA 2009, 302(17):1896 1902.

28. Jain S, Kamimoto L, Bramley AM, Schmitz AM, Benoit SR, Louie J, Sugerman DE, Druckenmiller JK, Ritger KA, Chugh R: Hospitalized patients with 2009 H1N1 influenza in the United States, April June 2009. N Engl J Med 2009, 361(20):1935 1944.

29. Kumar A, Zarychanski R, Pinto R, Cook DJ, Marshall J, Lacroix J, Stelfox T, Bagshaw S, Choong K, Lamontagne F: Critically ill patients with 2009 influenza A (H1N1) infection in Canada. JAMA 2009. 302(17):1872 1879.

30. Libster R, Bugna J, Coviello S, Hijano DR, Dunaiewsky M, Reynoso N, Cavalieri ML, Guglielmo MC, Areso MS, Gilligan T: Pediatric hospitalizations associated with 2009 pandemic influenza A (H1N1) in Argentina. N Engl J Med 2010, 362(1):45 55.

31. Iorio AM, Camilloni B, Basileo M, Monaldi L, Lepri E, Neri M, Marcucci M, Baldelli F: An observational retrospective study provide information on hospitalization and severe outcomes of the $2009 \mathrm{~A}(\mathrm{H} 1 \mathrm{~N} 1)$ infection in Italy. J Clin Med Res 2013, 5(4):286 293.

32. Venter M, Lassaunire R, Kresfelder TL, Westerberg Y, Visser A: Contribution of common and recently described respiratory viruses to annual hospitalizations in children in South Africa. J Med Virol 2011, 83(8):1458 1468.

33. Pretorius MA, Madhi SA, Cohen C, Naidoo D, Groome M, Moyes J, Buys A, Walaza S, Dawood H, Chhagan M, Haffjee S, Kahn K, Puren A, Venter M: Respiratory viral co-infections identified by a 10-plex real-time reverse-transcription polymerase chain reaction assay in patients hospitalized with severe acute respiratory illness South Africa, 2009 2010. J Infect Dis 2012, 206(Suppl 1):S159 S165.

34. Lee N, Lui GC, Wong KT, Li TC, Tse EC, Chan JY, Yu J, Wong SS, Choi KW, Wong RY, Ngai KL, Hui DS, Chan PK: High morbidity and mortality in adults hospitalized for respiratory syncytial virus infections. Clin Infect Dis 2013, 57(8):1069 1077

35. Falsey AR, Cunningham CK, Barker WH, Kouides RW, Yuen JB, Menegus M, Weiner LB, Bonville CA, Betts RF: Respiratory syncytial virus and influenza A infections in the hospitalized elderly. J Infect Dis 1995, 172(2):389 394.

36. McCracken JP, Prill MM, Arvelo W, Lindblade KA, Lopez MR, Estevez A, Muller ML, Munoz F, Bernart C, Cortez M, Moir JC, Ortiz J, Paredes A, Iwane MK: Respiratory syncytial virus infection in Guatemala, 2007 2012. J Infect Dis 2013, 208(Suppl 3):S197 S206.

37. Pretorius M, Tempia S, Walaza S, Cohen A, Moyes J, Hellferscee O, Variava E, Dawood H, Chhagan M, Haffjee S, Madhi S, Cohen C, Venter M: Association of influenza and other respiratory viruses with severe acute respiratory infection and influenza-like illness, relative to healthy controls in South Africa. In Proceedings of the 8th Options for the Control of Influenza Conference, 510 September 2013. Cape Town, South Africa; 2013: 569/P2-649.

38. Rowlinson E, Dueger E, Taylor T, Mansour A, Van Beneden C, Abukela M, Zhang X, Refaey S, Bastawy H, Kandeel A: Incidence and clinical features of respiratory syncytial virus infections in a population-based surveillance site in the Nile Delta Region. J Infect Dis 2013, 208(Suppl 3):S189 S196. 
39. Bigogo GM, Breiman RF, Feikin DR, Audi AO, Aura B, Cosmas L, Njenga MK, Fields BS, Omballa V, Njuguna H, Ochieng PM, Mogeni DO, Aol GO, Olack B, Katz MA, Montgomery JM, Burton DC: Epidemiology of respiratory syncytial virus infection in rural and urban Kenya. J Infect Dis 2013, 208(Suppl 3):S207 S216.

40. Naorat $S$, Chittaganpitch $M$, Thamthitiwat $S$, Henchaichon $S$, Sawatwong $P$, Srisaengchai P, Lu Y, Chuananon S, Amornintapichet T, Chantra S, Erdman DD, Maloney SA, Akarasewi P, Baggett HC: Hospitalizations for acute lower respiratory tract infection due to respiratory syncytial virus in Thailand, 2008 2011. J Infect Dis 2013, 208(Suppl 3):S238 S245.

41. Tempia S, Walaza S, Viboud C, Cohen AL, Madhi SA, Venter M: Mortality associated with seasonal and pandemic influenza and respiratory syncytial virus among individuals aged 5 years and older in a high HIV-prevalence setting - South Africa, 1998 2009. Emerg Infect Dis. In press

42. Thompson WW, Shay DK, Weintraub E, Brammer L, Cox N, Anderson L, Fukuda K. Mortality associated with influenza and respiratory syncytial virus in the United States. JAMA 2003, 289(2):179 186.

43. Osterholm MT, Kelley NS, Sommer A, Belongia EA: Efficacy and effectiveness of influenza vaccines: a systematic review and meta-analysis. Lancet Infect Dis 2012, 12(1):36 44.

44. Beeler JA, Eichelberger MC: Influenza and respiratory syncytial virus (RSV) vaccines for infants: safety, immunogenicity, and efficacy. Microb Pathog 2013, $55: 915$.

45. Michiels B, Govaerts F, Remmen R, Vermeire E, Coenen S: A systematic review of the evidence on the effectiveness and risks of inactivated influenza vaccines in different target groups. Vaccine 2011, 29(49):9159 9170.

doi:10.1186/s12879-014-0694-x

Cite this article as: Kyeyagalire et al.: Hospitalizations associated with influenza and respiratory syncytial virus among patients attending a network of private hospitals in South Africa, 2007 2012. BMC

Infectious Diseases 2014 14:694.

\section{Submit your next manuscript to BioMed Central and take full advantage of:}

$\bowtie$ Convenient online submission

$凶$ Thorough peer review

凶No space constraints or color $₫$ gure charges

$\otimes$ Immediate publication on acceptance

ه Inclusion in PubMed, CAS, Scopus and Google Scholar

$\triangle$ Research which is freely available for redistribution 